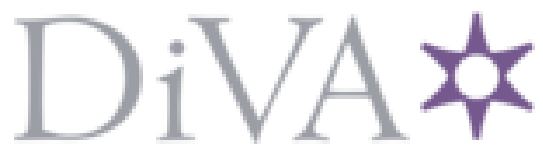

http://www.diva-portal.org

This is the published version of a paper presented at EGU General Assembly 2021.

Citation for the original published paper:

Malehmir, A., Darvishi, M., Nilfouroushan, F. (2021)

Integration of InSAR and ground-based geophysical measurements to study an area prone to quick-clay landslide in Sweden

In: EGU General Assembly 2021

N.B. When citing this work, cite the original published paper.

Permanent link to this version:

http://urn.kb.se/resolve?urn=urn:nbn:se:hig:diva-35210 
EGU21-15677

EGU General Assembly 2021

(c) Author(s) 2021. This work is distributed under

the Creative Commons Attribution 4.0 License.

\title{
Integration of InSAR and ground-based geophysical measurements to study an area prone to quick-clay landslide in Sweden
}

\author{
Alireza Malehmir ${ }^{1}$, Mehdi Darvishi' ${ }^{2}$, and Faramarz Nilfouroushan ${ }^{3,4}$ \\ ${ }^{1}$ Dept. of Earth Sciences, Uppsala University, Uppsala, Sweden \\ ${ }^{2}$ Dept. of Physical Geography, Stockholm University, Stockholm, Sweden \\ ${ }^{3}$ Faculty of Engineering and Sustainable Development, University of Gävle, Gävle, Sweden \\ ${ }^{4}$ Dept. of Geodetic Infrastructure, Geodata Division, Lantmäteriet, Gävle, Sweden
}

Landslides and floods are the two most important geohazards in Sweden. Due to the climate change effects, it is believed that the risk of occurring these geohazards will increase in Sweden causing for example the land to become more prone to landslides. Additionally, due to the isostatic uplift caused by the retreating of the ice sheet, approximately 10,000 years ago, marine sediments involving marine clays have become exposed above sea level in Scandinavia. Infiltration of fresh water has (and is) leached the salt from the pores within the marine clays leading to the formation a special kind of clay known as the quick clay in the northern countries. These glacial clays and postglacial silts cause more ground surface instability and become slops more prone to trigger landslides, which is the case for concentration of the most landslides in the southwest of Sweden. Hence, quick-clay landslides are common geohazards in Nordic countries, which potentially could cause a considerable economical and live cost. The most recent Gjerdurm landslide in Norway was of this kind quick-clay related.

In recent years, an area close to the Göta River of southeast of Sweden has been the subject of numerous surface and airborne geophysical surveys for detailed subsurface mapping and delineation of the quick-clay and sediments hosting them including the very undulating the crystalline bedrock. These existing studies including access to borehole observations and geotechnical studies motivated us to study also long-term surface deformation in order to study climate effects, erosion, precipitation and underlying quick-clay presence in this area and neighboring regions. We employed radar data with Syntenic Aperture Radar (SAR) interferometry techniques. To this end, Sentinel-1 data from 2015 to 2019 were processed with the Small BAsline Subset (SBAS) technique to estimate time-series displacements and to generate deformation map for that region. The initial results show that the heterogenous deformation observed in the study area with maximum subsidence rate of $-22 \mathrm{~mm} / \mathrm{yr}$. The deforming areas appear to be located on regions with the thickest column of the clay near the river where we anticipate also thicker quickclay layers present. The quick-clays in this region overlie a thick (ca. $20 \mathrm{~m}$ ) coarse-grained layer interpreted from the surface geophysical measurements to be associated with the formation and triggering of quick-clays in the area. With such a large surface deformation and the underling geology, we observe two phenomena in the study. A possible sudden risk of quick-clay landslide but also a long-term creeping of clays and destabilizing effect that may accelerate erosion at the 
river bank causing more landslides in the future. The cause of the large deformation is still unclear and will be investigated together with hydrogeological and geophysical data available in the study. This study however provides compelling evidence of major surface deformation that should be considered for long-term risk mitigation and planning. 